\title{
SUBJEKTIVITAS KEKUASAAN DALAM PEMBERITAAN MEDIA ONLINE
}

\section{POWER SUBJECTIVITY IN MEDIA ONLINE COVERAGE}

\author{
Launa $^{1}$ dan Samdar Rery ${ }^{2}$ \\ ${ }^{1}$ Program Studi Ilmu Komunikasi FISIP Universitas Bung Karno \\ Jl. Pegangsaan Timur No.17A, Menteng, Jakarta, Indonesia \\ ${ }^{2}$ STIKOM Muhammadiyah Jayapura \\ Jl. Abepantai No. 25, Tanah Hitam, Abepura, Jayapura, Indonesia \\ 1launa2011@gmail.com; ${ }^{2}$ sam_rery16@gmail.com \\ Diterima tgl. 26/2/2019; Direvisi tgl. 12/5/2020; Disetujui tgl. 18/5/2020
}

\begin{abstract}
At present, the social media newsroom has been widely used to branding images that are certain political symbols, while deconstructing political images. The news portal Detik.com and Kompas.com include those that are widely used to construct or deconstruct certain political images. In the year of politics, where presidential elections will be held, it is difficult to avoid the subjectivity of power sneaking into the media room. This fact is proven through the study of the reporting of the hashtag (\#)2019overthepresident's on the news portal Detik.com and Kompas.com. This descriptive-interpretive qualitative study with the Pan-Kosicki framing analysis found an element of subjectivity in discourse \#2019overthepresident's on both news portals. Judging from the syntactic, script, thematic, and rhetorical elements of analysis there are aspects of subjectivity in the news Detik.com and Kompas.com. Through the language analysis tool on the four elements of Pan-Kosicki, found a tendency to positive framing on \#2019Ganti President's hashtag at Detik.com. On the contrary, Kompas.com tends to give negative framing on \#2019overthepresident's hashtag. There is power subjectivity in news framing in both sample media with different variations, accents, and degrees.
\end{abstract}

Keywords: Hashtag, News Framing, Social Construction, Power Subjectivity.

\begin{abstract}
ABSTRAK
Saat ini ruang berita media sosial telah banyak digunakan untuk mem-brading citra yang menjadi simbol politik tertentu, sekaligus mendekonstuksi citra politik. Portal berita Detik.com dan Kompas.com termasuk yang cukup banyak dimanfaatkan untuk mengonstruksi atau mendekonstruksi citra politik tertentu. Di tahun politik, ketika pemilihan presiden akan digelar, sulit dihindari subjektivitas kekuasaan menyelinap masuk ke ruang media. Fakta ini dibuktikan melalui kajian pemberitaan tagar (\#)2019GantiPresiden di portal berita Detik.com dan Kompas.com. Penelitian ini merupakan penelitian kualitatif bersifat deskriptif-interpretif dengan analisis framing Pan-Kosicki untuk menemukan adanya unsur subjektivitas pemberitaan media online terkait wacana \#2019GantiPresiden di kedua portal berita. Hal tersebut dapat diketahui dari elemen analisis sintaksis, skrip, tematik, dan retoris terdapat aspek subjektivitas dalam pemberitaan Detik.com dan Kompas.com. Melalui analisis bahasa pada keempat elemen analisis Pan-Kosicki, ditemukan kecenderungan framing positif pada tagar \#2019GantiPresiden di Detik.com. Sebaliknya, Kompas.com cenderung memberi framing negatif pada tagar \#2019GantiPresiden. Terdapat subjektivitas kekuasaan dalam framing berita di kedua media sampel dengan variasi, aksentuasi, dan derajat yang berbeda.
\end{abstract}

Kata Kuci: Tagar, Framing Berita, Konstruksi Sosial, Subjektivitas Kekuasaan.

\section{PENDAHULUAN}

Media massa adalah tempat yang paling efektif untuk menyemai informasi kepada publik. Media memiliki andil besar dalam menarasikan sebuah peristiwa: bagaimana sebuah peristiwa dilihat, dimaknai, dipahami, dan disimpulkan oleh masyarakat. Melalui teks berita yang disajikan, media bisa membuat opini publik begeser: positif, negatif atau netral. Kasus kemenangan pasangan Joko Widodo-Jusuf Kalla dalam pilpres 2014 misalnya-yang diawali oleh kemenangan pasangan Joko Widodo-Basuki Tjahaja Purnama dalam Pilgub DKI Jakarta 2012-menjadi bukti nyata 
bagaimana media bisa menggeser opini publik. Bukan sesuatu yang berlebihan jika Althusser (2015) menyebut media sebagai 'aparatus ideologis', alat 'hegemoni' (Gramsci dalam Boothman, 2008) atau alat politisasi yang bisa mengintervensi ruang publik demokratis (Habermas, 2007).

Secara konseptual, objektivitas media adalah kemampuan wartawan/media dalam mengambil jarak atau berposisi netral dengan menanggalkan pendapat atau opini pribadi wartawan/media atas objek pemberitaan (McQuail, 1991). Wasterstahl (dalam McQuail, 1991) menyebut objektivitas pemberitaan meliputi dua konsep utama. Pertama, imparsialitas (sikap nonpartisan) mencakup aspek balance (sikap berimbang) dan neutrality (sikap netral); dan kedua, faktualitas yang mencakup aspek truth (kebenaran), relevance (relevansi) dan informativeness (bersifat informatif).

Studi tentang subjektivitas kekuasaan (power subjectivity) pernah dilakukan oleh Hayakawa (1990). Riset Hayakawa memberi petunjuk terkait perdebatan konsep objektivitas dan subjektivitas dalam pemberitaan media melalui penggunaan konsep validasi dan verifikasi terhadap objek berita untuk menghindari inference (bias kesimpulan), judgement (penilaian keliru), dan slanting (memilih bahan yang sesuai atau tidak sesuai dengan materi yang sedang dideskripsikan). Studi Merrill, How Time Stereotype Theree U.S Presidents (1965) juga ditujukan untuk mengukur sejauh mana bias sebuah berita dengan menggunakan konsep semantika bahasa terkait stereotype tiga calon presiden Amerika Serikat. Menurut Severin dan Tankard (2011), Merrill dalam studinya menemukan enam pengelompokan jenis bias dalam pemberitaan media massa di Amerika Serikat, yakni attribution bias, adjective bias, adverbial bias, outright opinion, contextual bias, dan photographic bias. Merrill menyimpulkan ada bias negatif terhadap Harry S. Truman, bias positif terhadap Dwight D. Eisenhower, dan peliputan yang berimbang terhadap John F. Kennedy.

Bisa dikatakan panggung kontestasi pilpres 2019 memainkan unsur branding politik melalui tagar (\#)2019GantiPresiden. Terkait hal itu, media ditengarai punya kepentingan untuk menyajikan berita dengan framing tertentu. Habermas (2007) menyebut realitas ini sebagai 'polarisasi ruang sosial' karena ruang sosial (realitas faktual) menjadi semacam panggung sosial (realitas artifisial). Dunia faktual yang telah terepresentasi ke dalam dunia simbolik yang dilahirkan media dari produksi sosial seringkali menjadi alat kontrol kekuasaan. Ruang sosial terkonstruksi dari aktivitas manusia; dan aktivitas manusia kemudian kembali dibentuk oleh ruang sosial (Lefebvre, 2000).

Pertanyaannya, apakah tagar atau hashtag (\#)2019GantiPresiden adalah varian dari ruang sosial perluasan bahasa komunikasi pada teks media yang bisa digunakan sebagai saluran politik yang memungkinkan komunikan (peng-uploadluploader teks) melakukan komunikasi langsung dengan komunikan (follower/konsumen teks)? Sebab, pola komunikasi politik yang berlangsung di jejaring media sosial ini akan memberi pengaruh — di level individu maupun kolektif-pada pesanpesan komunikasi politik yang terus bergerak secara dinamis, bahkan cenderung disruptif.

Kehadiran tagar ( hastag) juga dapat dipahami sebagai bentuk baru dari era politik virtual yang hadir sebagai hasil dari produk revolusi digital 4.0. Salah satu peran penting media sosial di era virtual adalah memainkan isu berbasis citra, simbol, slogan atau jargon. Realitas politik citra memungkinkan wacana politik dikonstruksi dengan dunia teknologi informasi digital yang saat ini telah disesaki beragam citra, simbol, slogan, dan jargon politik. Dunia politik pada akhirnya melakukan transfomasi ke ranah permainan politik (political games) yang bersifat simbolik-virtual untuk meraih target politis di era industri politik yang kian berwajah 'digitalized' (Piliang, 2004).

Kajian ini ditujukan untuk menelaah unsur subjektivitas kekuasaan pada pemberitaan media melalui analisis (tagar) \#2019GantiPresiden di laman Detik.com dan Kompas.com. Subjektivitas kekuasaan akan dikaji dengan analisis framing model Pan-Kosicki. Dari sisi akademis, hasil kajian diharapkan dapat memberikan kontribusi terkait subjektivitas kekuasaan dalam teksasi berita di media online. Sementara dari sisi praktis, hasil kajian ini diharapkan dapat memberi kontribusi 
praktis bagi wartawan dan para pekerja media agar bersikap netral dan objektif karena posisi media sangat strategis sebagai pengawas (watch dog) dan pilar keempat demokrasi (the fourth estate).

\subsection{Objektivitas dan Subjektivitas Media}

Menjelang kontestasi pilpres 2019, tagar politik menjadi salah satu kekuatan politik simbolik yang digunakan parpol atau aktor politik untuk meraih dukungan politik publik. Namun, strategi komunikasi politik melalui media sosial yang dikelola secara tidak hati-hati dapat melahirkan kedangkalan dan disorientasi politik publik. Komunikasi politik sebagai wahana penggiringan opini publik tidak bisa dilepaskan dari ambisi pribadi politisi dan kepentingan media untuk kebutuhan propaganda politik (Jackal, 1995; Edelstein, 1997; Mirriam Webster, 2006). Setiap bentuk propaganda politik akan dikonstruksi melalui pelibatan sentimen (emosi) publik serta upaya persuasi publik untuk melayani tujuan propagandis dengan menyebarluaskan simbol-simbol politik, ideologi, atau doktrin tertentu (Jowett dan O'Donnell, 2012; Scriver, 2015).

Perspektif pluralis memandang pekerja media (wartawan, redaktur) dan pemilik (perusahaan) media sebagai entitas yang otonom (objektif), sehingga berita yang dihasilkan adalah reflikasi dari realitas faktual yang ada di lapangan. Sementara paradigma konstruktivis dan kritis mamandang wartawan/pemilik media sebagai entitas yang tidak netral karena aktivitas media terkait erat dengan struktur sosial, budaya, dan konfigurasi kekuatan politik yang ada dalam masyarakat.

Sebagai alat untuk menarasikan pesan, media massa tidak hanya memiliki kemampuan untuk berperan sebagai pembentuk opini publik (public opinion maker), akan tetapi media massa bisa juga memerankan dirinya sebagai kelompok penekan (pressure group) atas suatu pandangan/opini yang dipaksakan untuk diterima pihak lain (Sobur, 2012). Dalam relasinya dengan kekuasaan, media adalah alat legitimasi kekuasaan, bahkan instrumen kekuasaan negara (Althusser, 2015).

Untuk memahami bagaimana subjektivitas kekuasaan beroperasi dalam pemberitaan media Detik.com dan Kompas.com, kita harus menempatkan kajian ini dalam pemahaman paradigma konstruksi sosial dari Berger dan Luckmann (1966). Menurut Berger dan Luckmann, memahami konstruksi sosial adalah memahami manusia sebagai produk dialektis antara dirinya (the self) dan relasinya dengan dunia sosiokultural. Masyarakat adalah produk konstruksi manusia, dan sebaliknya manusia adalah produk konstruksi masyarakatnya. Dengan demikian, realitas sosial merupakan hasil konstruksi sosial yang diciptakan oleh manusia (Berger dan Luckmann, 1990).

Thomas Khun (dalam Adian, 2002) melihat konstruktivisme sebagai pandangan yang meyakini bahwa semesta secara epistemologi merupakan hasil konstruksi sosial manusia yang dilatari oleh kemampuan inderawi, intelektual, budaya, dan bahasa. Dahlgren (dalam Adian, 2002) menyebut realitas sosial sebagai produk manusia, hasil proses budaya, yang terkonstruksi melalui bahasa sebagai sarana dalam memaknai dan berelasi dengan lingkungan sosiokulutralnya. Poloma (2010) dan Bungin (2015) juga memahami realitas yang ditampilkan media merupakan hasil konstruksi manusia secara sosial, yang pemaknaannya tidak bisa dilepaskan dari pengaruh lingkungan sosial, budaya, dan kekuasaan yang melingkupinya.

Pemahaman paradigma konstruksi sosial dengan penekanan pada praktik bahasa dalam kajian ini mengacu pada gagasan Berger dan Luckmann, Hamad, dan Eriyanto. Bagi Berger dan Luckmann (1990), bahasa tidak hanya mampu mengonstruksi simbol-simbol yang dapat diabstraksikan dari pengalaman hidup sehari-hari, melainkan bahasa juga mampu 'mengembalikan' simbol-simbol itu dan menghadirkannya sebagai unsur yang objektif dalam kehidupan sehari-hari.

Senada dengan Berger dan Luckmann, Hamad (2004) juga menyebut elemen utama konstruksi realitas adalah bahasa, baik dalam bentuk verbal (kata-kata lisan dan tulisan) maupun nonverbal (gambar, foto, grafik, angka atau tabel). Pemilihan kata, struktur bahasa, cara penyajian atau penampilan secara keseluruhan sebuah teks dalam menyusun fakta berita dapat menentukan bentuk 
konstruksi realitas yang sekaligus akan menghasilkan makna tertentu darinya, termasuk pilihan kata (diksi) untuk memanipulasi realitas faktual.

Sementara bagi Eriyanto (2002), fakta dan makna yang terkonstruksi dalam sebuah berita sangat tergantung dari peta konsep (ide, pikiran) dan mental (suasana batin, psikis) yang ada di kepala si wartawan selaku konstruktor berita. Karena peta konsep dan mental si wartawanlah yang sesungguhnya terlibat dalam pembentukan fakta dan pendefinisian makna tentang bagaimana, dengan cara apa, dan untuk tujuan atau kepentingan apa sebuah berita ditulis dan disajikan.

Di sisi lain, Althusser (2015) memosisikan media sebagai aparatus ideologis. Gramsci (dalam Ramos, 1982) melihat media sebagai arena pertarungan ideologi yang berkompetisi untuk merajut konsensus sosial. Disini, media bisa berposisi subjektif, berfungsi sebagai alat penyebaran ideologi penguasa, alat legitimasi, sekaligus alat untuk mengontrol wacana publik. Media juga bisa menjadi alat resistensi atas dominasi atau legitimasi kekuasaan yang kadar subjektivitasnya bisa beroperasi melalui bahasa (praktik wacana). Media juga bisa menjadi alat kritik wacana (counter discourse), alat perlawanan budaya (counter culture), alat delegitimasi hegemoni (counter hegemony), bahkan alat konstruksi ideologi tandingan (counter ideology). Dalam posisi dikotomis Althusser-Gramsci inilah subjektivitas kekuasaan dalam pemberitaan media kita tempatkan sebagai define of problem.

Lalu bagimana subjektivitas kekuasaan dimaknai dalam paradigma konstruktivis? Kehadiran realitas sosial yang dikonstruksi media pada hakikatnya terkait erat dengan strategi kekuasaan yang terefleksi melalui wacana; dan dari sanalah kita bisa mendeteksi unsur subjektivitas (bias atau keberpihakan) dalam pemberitaan media (Fillingham, 2001). Menurut Foucault, subjektivitas kekuasaan dibentuk oleh sistem dominan dari organisasi sosial yang bertujuan mengatur manusia: 'rasa tunduk, di bawah kendali sesuatu di luar dirinya' ('a sense of being subject to, under the control of something external to ourself). Dalam The Archaeology of Knowledge (1972), Foucault menyebut operasi kekuasaan (power operation) tidak bisa dilepaskan dari wacana (claim of truth) yang memengaruhi institusi-institusi sosial dan praktik-praktik sosial. Bagi Foucault, kekuasaan tidak beroperasi secara negatif melalui aparatus yang koersif, tetapi kekuasaan beroperasi secara positif dan produktif melalui wacana (discourse) yang dihasilkannya (Kamahi, 2017).

Peter D. Moss (1999) menyebut wacana media merupakan konstruksi kultural yang dihasilkan oleh ideologi. Lewat narasinya, media akan selalu mengonstruksi realitas sosial dengan membentuk definisi dan konsep tertentu untuk memahami, memaknai, mengarahkan, bahkan menentukan realitas sosial kehidupan manusia (Hamad, 2004; Muslich, 2008). Sementara bagi Giles dan Middleton (dalam Ayuningtyas, 2009), subjektivitas adalah suatu pengalaman yang terbuka untuk ketidakkonsistenan, kontradiksi, dan kesadaran-bukan diri yang berlangsung dalam praktik wacana.

Kekuasaan yang dimaksud dalam kajian ini adalah hadirnya fenomena relasi-relasi kuasa yang bergerak secara resiprokal di antara institusi media dan institusi politik, dan sebaliknya, di antara institusi politik dan institusi media. Menurut Foucault (dalam Mujianto, 2011), kekuasaan sering tampak dan mewujud dalam praktik bahasa (language practice). Karena bahasa adalah alat efektif bagi 'si kuat' untuk mendominasi 'si lemah'. Kekuasaan adalah wilayah strategis, tempat terjadinya hubungan yang tidak setara antara si kuat dan si lemah itu; sebuah relasi asimetris antara produsen teks (wartawan/media) dan konsumen teks (khalayak pembaca).

Menurut Fowler (1991), kuasa dapat dimaknai sebagai kemampuan seseorang atau institusi dalam mengontrol perilaku dan kehidupan material orang lain. Kuasa memproduksi realitas, lingkup objek, dan ritus-ritus kebenaran. Kuasa berjalan melalui normalisasi dan regulasi. Kuasa mengandaikan adanya ketidaksetaraan antarpartisipan dalam peristiwa-peristiwa wacana, ada ketidaksamaan kapasitas dalam mengontrol bagaimana sebuah wacana diproduksi, didistribusi, dan dikonsumsi dalam ruang politik dan lingkungan sosial-budaya (Fairclough, 1995). 
Kekuasaan dalam kajian ini juga mengacu pada perspektif dinamika politik media. Dinamika politik media saat ini praktis telah mengalami pegeseran pola relasi secara signifikan, baik antara media dan kekuasaan maupun antara kekuasaan dan media (Croteau dan Hoynes, 2000). Pertama, politik media terus berkembang di tengah menguatnya fenomena konglomerasi dan konsentrasi kepemilikan media. Keduanya telah memicu dampak nyata pola relasi dalam institusi media dan proses demokratisasi politik secara luas dalam kehidupan publik. Kedua, dampak yang ditimbulkan dari sisi proses demokratisasi adalah menguatnya ketegangan antara structure dan agency.

'Agen' (agency) merujuk pada kapasitas seseorang untuk bertindak secara independen dan membuat pilihan mereka sendiri. 'Struktur' (structure) secara luas merujuk pada penataan terpola berulang yang memengaruhi atau membatasi pilihan/kesempatan yang dimiliki seseorang (Giddens, 2010). Ketegangan dialektis antara agen dan struktur ini telah memberi pengaruh terhadap pola relasi diantara kekuatan-kekuatan politik (formal maupun informal) yang bertarung di luar media, sekaligus memberi pintu masuk bagi peningkatan peran media dalam kehidupan politik.

Menurut Fazarinc (dalam Meyers dan Gerstman, 2001), branding telah menjadi ajang promosi dari proses pengelolaan konsep bisnis terkait janji perusahaan penghasil produk bisnis. Branding juga bisa digunakan sebagai strategi sentuhan emosional yang terbukti efektif merubah persepsi konsumen (Kotler dan Pfoertsch, 2006). Artikulasi identitas diri konsumen juga dapat dilihat dari citra visual yang terpancar pada pemberitaan media (Schroeder, 2002). Dalam politik, konsep branding dipakai sebagai sarana pengelolaan konsep, komitmen, dan citra politik dari parpol atau aktor politik pada melalui media sosial yang saat ini telah digunakan secara luas oleh publik.

Sebagai metode analisis yang mengacu pada payung paradigma konstruksionis, analisis framing adalah metode yang sering digunakan untuk melihat bagaimana media mengonstruksi realitas; bagaimana suatu isu/peristiwa dilihat, dipahami, dan dibingkai oleh media. Framing adalah cara bagaimana kita melihat berita dari jendela dunia (ada fakta yang ditonjolkan, disamarkan, disembunyikan, dihilangkan dari narasi/teks berita). Framing adalah cara bagaimana media mengonstruksi realitas, karena realitas bukanlah sesuatu yang taken for granted. Framing adalah metode untuk melihat cara media bercerita (story telling) atas fakta berita yang akan dijadikan objek penulisan. Dalam framing, wartawan/medialah yang aktif membentuk realitas.

\subsection{Framing Pan-Kosicki}

Sesuai dengan sifat paradigma konstruktivis, kajian ini akan diarahkan untuk melihat bagaimana Detik.com dan Kompas.com mengonstruksi berita tagar (\#)2019GantiPresiden ditinjau dari analisis framing Pan-Kosicki. Unit pengamatan atau objek studi (focus of study) adalah teks berita Detik.com dan Kompas.com. Sementara satuan (unit) analisisnya adalah teks-teks berita tagar (\#)2019GantiPresiden yang teksasinya tersaji dalam pemberitaan di kedua portal berita.

Menurut Pan dan Kosicki, framing adalah: (1) strategi konstruksi dalam memproses berita, dimana perangkat kognisi digunakan untuk mengkode informasi dan menafsirkan peristiwa yang dihubungkan dengan rutinitas dan konvensi pembentukan berita; (2) cara media bercerita yang dikemas (package) ke dalam skema (struktur pemahaman) yang dipakai individu untuk mengonstruksi makna pesan-pesan, serta menafsirkan makna pesan-pesan yang ia terima; (3) melihat teks berita dari berbagai simbol, sebagai seperangkat kode yang membutuhkan intepretasi; (4) sebagai alternatif dalam analisis teks media, dengan tujuan untuk melihat suatu isu, kebijakan atau wacana publik yang dikonstruksi dan dinegosiasi media (Nazaruddin, 2015).

Menurut Pan-Kosicki, framing adalah sebuah proses penyusunan pesan yang menempatkan informasi yang ingin disampaikan dikonstruksi lebih menonjol ketimbang informasi yang lain. Tujuannya agar khalayak pembaca lebih fokus pada informasi yang dikonstruksi lebih menonjol tersebut (Eriyanto, 2002). Dalam teorinya, Pan-Kosicki membagi perangkat analisisnya ke dalam 
empat struktur, yakni: (1) struktur sintaksis (berhubungan dengan headline berita, lead berita, latar informasi, pernyataan, opini, kutipan, pengamatan atas peristiwa ke dalam bentuk susunan kalimat); (2) struktur skrip (berhubungan dengan cara wartawan dalam mengisahkan berita dan mengemas peristiwa); (3) struktur tematik (hubungan antar kalimat yang membentuk teks secara keseluruhan); dan (4) struktur retoris (berhubungan dengan cara wartawan memakai pilihan kata, idiom, grafik atau gambar yang digunakan untuk mendukung framing berita).

Tabel 1. Kerangka Framing Zhongdang Pan dan Gerald M. Kosicki

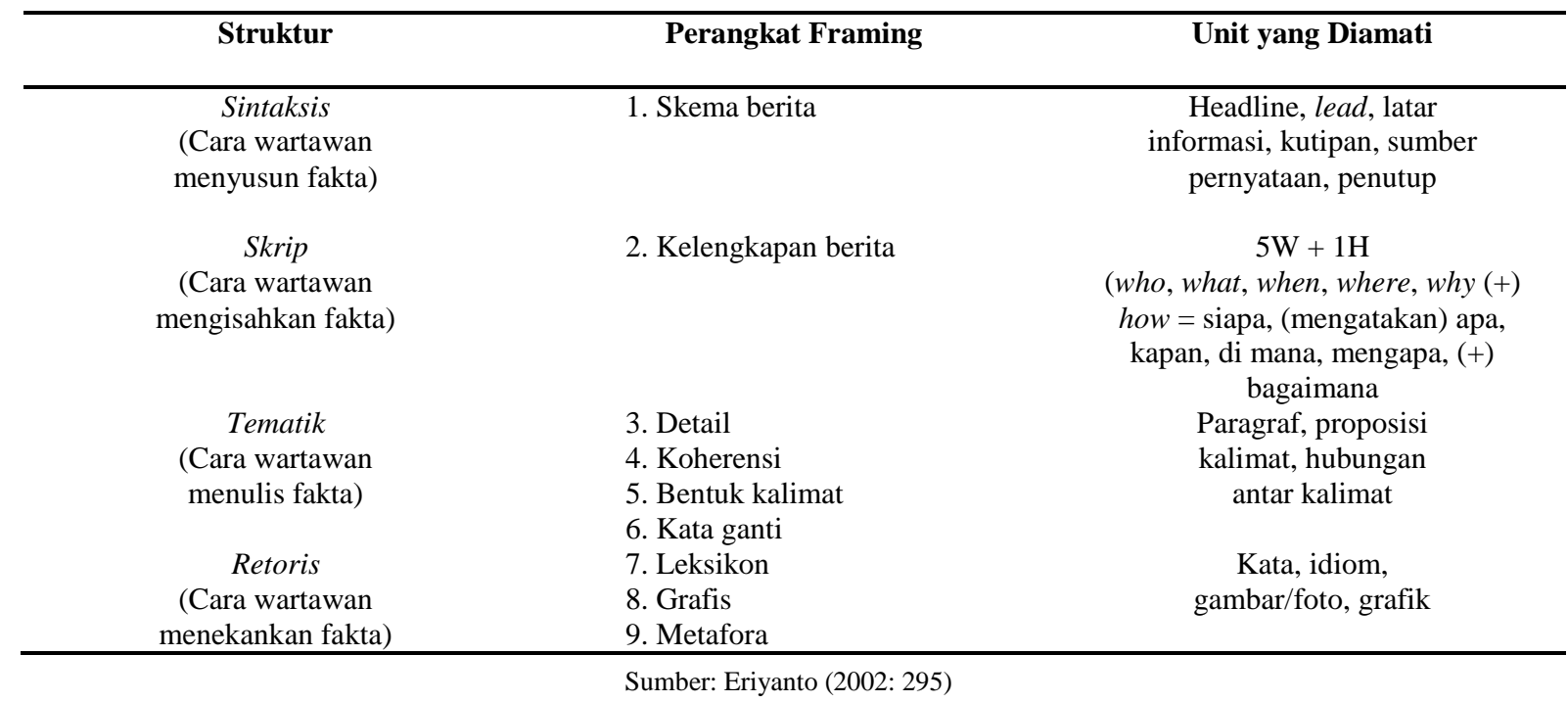

Analisis framing dalam kajian ini dibatasi pada level naskah teks berita (single level analysis) (Hamad, 2007). Melalui kajian pada level teks berita, studi ini berupaya mengeksplorasi informasi secara lebih sistematis, utuh dan mendalam terkait konstruksi realitas berita serta menemukan aspek subjektivitas kekuasaan yang manifestasinya terepresentasikan dalam teks berita tagar (\#)2019GantiPresiden.

\section{METODE PENELITIAN}

Kajian ini menggunakan paradigma konstruktivis, dengan pendekatan kualitatif dan metode analisis framing berita yang bersifat deskriptif-interpretif. Pendekatan kualitatif memusatkan perhatian pada prinsip-prinsip umum yang mendasari perwujudan sebuah makna dari gejala-gejala sosial yang ada (Bungin, 2006). Objek analisis pendekatan kualitatif berbasis framing adalah deskripsi atas makna penggunaan bahasa. Tujuannya adalah untuk mendapat gambaran sistematis mengenai pola/kategorisasi tertentu dari teks berita hasil produksi media. Sementara Perspektif interpretif memandang realitas sosial sebagai fenomena yang holistik, kompleks, dinamis, penuh makna, dan relasi antar gejala bersifat timbal balik (reciprocal) (Rahardjo, 2018).

Adapun metode analisis framing umumnya digunakan untuk telaah teks (text), studi wacana (discourse) atau analisis isi media (content analysis) karena teks berita yang tersaji dalam media (penggunaan bahasa, praktik wacana, dan produk penandaan) menjadi fokus utama telaahnya. Analisis framing masuk dalam kategori penelitian dengan paradigma interpretif pada jenis paradigma penelitian konstruktivis yang bersifat transactional dan subjective.

Sumber data yang digunakan dalam kajian ini adalah teks berita \#2019GantiPresiden yang termuat pada laman portal berita Detik.com dan Kompas.com. Data yang digunakan adalah teks berita yang termuat sebagai objek teks berita di Detik.com dan Kompas.com edisi April-Mei 2018. Selama periode April-Mei 2018, portal berita Detik.com memuat enam teks berita terkait isu \#2019GantiPresiden (edisi 07 April, 08 April, 09 April, 21 April, 06 Mei, dan 25 Mei). Portal 
berita Kompas.com memuat tujuh teks berita (edisi 04 April, 07 April, 10 April, dan edisi 06 Mei sebanyak tiga teks berita). Dari 13 teks berita terkait pemberitaan tagar (\#)2019GantiPresiden yang telah di-publish oleh kedua portal berita tersebut (populasi), hanya empat teks berita yang dipilih secara purposif sebagai sampel untuk dianalisis (seperti terlihat dalam tabel berikut).

Tabel 2. Judul berita Detik.com dan Kompas.com Edisi April-Mei 2018

\begin{tabular}{ccc}
\hline No. & Teks Berita Detik.com & \multicolumn{1}{c}{ Update } \\
\hline 1. & "Jokowi Sindir \#2019GantiPresiden: Masak Kaus Bisa Ganti Presiden?" & 07 April 2018 | 14:36 WIB \\
\hline 2. & "Relawan \#2019GantiPresiden Bacakan Aspirasi Nasional, Ini Isinya" & 06 Mei 2018 | 10:10 WIB \\
\hline \multicolumn{3}{c}{ Teks Berita Kompas.com } \\
\hline 3. & "Muncul Tagar \#2019GantiPresiden, PPP Usul Tagar \#Lanjutkan212” & 04 April 2018 | 18:18 WIB \\
\hline 4. & "Sejumlah Anak Turut Kenakan Kaus \#2019GantiPresiden di CFD” & 06 Mei 2018|11:18 WIB \\
\hline
\end{tabular}

Teknik pengumpulan data yang digunakan adalah teknik dokumentasi. Pengumpulan data primer (primary-sources) teks berita \#2019GantiPresiden diambil dari Detik.com dan Kompas.com. Data yang terkumpul kemudian dianalisis dengan teknik analisis kualitatif (deskriptif-interpretif). Data lain yang digunakan adalah data sekunder (secondary-sources) dan data tersier (tertiersources), seperti buku, jurnal, dokumen, dan tulisan di website.

Teknik analisis yang digunakan adalah analisis framing model Zhongdang Pan dan Gerald M. Kosicki. Model analisis framing Pan-Kosicki dilatari oleh asumsi bahwa setiap berita memiliki struktur frame yang berfungsi sebagai pusat dari organisasi ide. Perangkat analisis Pan-Kosicki ini terdiri dari empat struktur, yakni: (1) struktur sintaksis; (2) struktur skrip; (3) struktur tematik; dan (4) struktur retoris. Masing-masing struktur analisis memiliki fungsi tersendiri dalam satuan-satuan analisis framing berita (bagaimana fakta berita disusun melalui praktik bahasa, bagaimana wacana dibangun, dan bagaimana proses penandaan diproduksi) (seperti terlihat pada tabel $1 \mathrm{di}$ atas).

Teknik analisis data dilakukan melalui tahapan berikut: (1) pengumpulan dan klasifikasi data; (2) identifikasi teks berita yang disusun dalam satuan-satuan analisis; (3) kategorisasi bagianbagian teks berita yang akan dianalisis; (4) interpretasi dan analisis teks berita; (5) komparasi teks berita Detik.com dan Kompas.com untuk melihat variasi perbedaan subjektivitas kekuasaan pada teks berita di kedua portal berita; dan (6) penarikan kesimpulan.

\section{HASIL DAN PEMBAHASAN}

\subsection{Deskripsi Objek Kajian}

Kompas.com adalah salah satu pionir media online di Indonesia ketika pertama kali hadir di internet (daring) pada 14 September 1995 dengan nama Kompas Online (KOL). Mulanya, KOL yang diakses dengan alamat kompas.co.id hanya menampilkan replika dari berita-berita harian Kompas versi cetak. Tujuan penerbitan edisi online untuk memberi layanan kepada para pembaca harian Kompas di tempat-tempat yang sulit dijangkau oleh jaringan distribusi Kompas versi cetak. Dengan kehadiran KOL, para pembaca setia harian Kompas cetak-khususnya di kawasan Timur Indonesia — dapat membaca berita Kompas secara online (https://inside.Kompas.com/about-us).

Di awal tahun 1996 alamat KOL berubah ke www.Kompas.com. Dengan alamat baru, KOL menjadi kian populer. Pengunjung KCM meningkat pesat seiring dengan tumbuhnya pengguna internet di Indonesia. Produktivitas sajian berita ditingkatkan dan kanal-kanal berita ditambah. Perubahan ini mendorong bertambahnya pengunjung aktif Kompas.com di awal tahun 2008 yang mencapai 20 juta pembaca per bulan (total 40 juta page views). Saat ini, pengunjung Kompas.com telah mencapai 120 juta pageview per bulan (https://nasional.Kompas.com/read/2017/09/13/ 12371281/kompascom-dan-14-september-1995).

Sementara itu, Detik.com adalah sebuah portal web yang berisi berita dan artikel daring di Indonesia. Detik.com hanya memiliki edisi daring dan sepenuhnya menggantungkan pendapatan 
dari bidang iklan (https://id.wikipedia.org/wiki/DetikCom). Melalui kerja keras Budiono Darsono (eks wartawan DeTik), Yayan Sofyan (eks DeTik), Abdul Rahman (eks Tempo) dan Didi Nugrahadi, Detik.com hadir sebagai penerbitan online (portal berita) berbasis internet di tengah situasi krisis ekonomi 1997. Di awal operasinya, Detik.com lebih terfokus pada berita politik, ekonomi, dan teknologi informasi. (https://greenp4r4hyangan.wordpress.com/2012/04/07/sejarahberdirinya-detik-com/). Pada 03 Agustus 2011, CT Corp mengakuisisi Detik.com (PT. Agrakom). Sejak itulah secara resmi Detik.com berada di bawah Trans Corp. Chairul Tanjung, pemilik CT Corp, membeli Detik.com secara total (100 persen) dengan nilai US\$60 juta atau Rp 521-540 miliar (https://id.wikipedia.org/wiki/ DetikCom).

\subsection{Penyajian Data dan Analisis}

Tabel 3. Framing Berita Detik.com (Teks Berita 1)

Judul: “Jokowi Sindir \#2019GantiPresiden: Masak Kaus Bisa Ganti Presiden?"

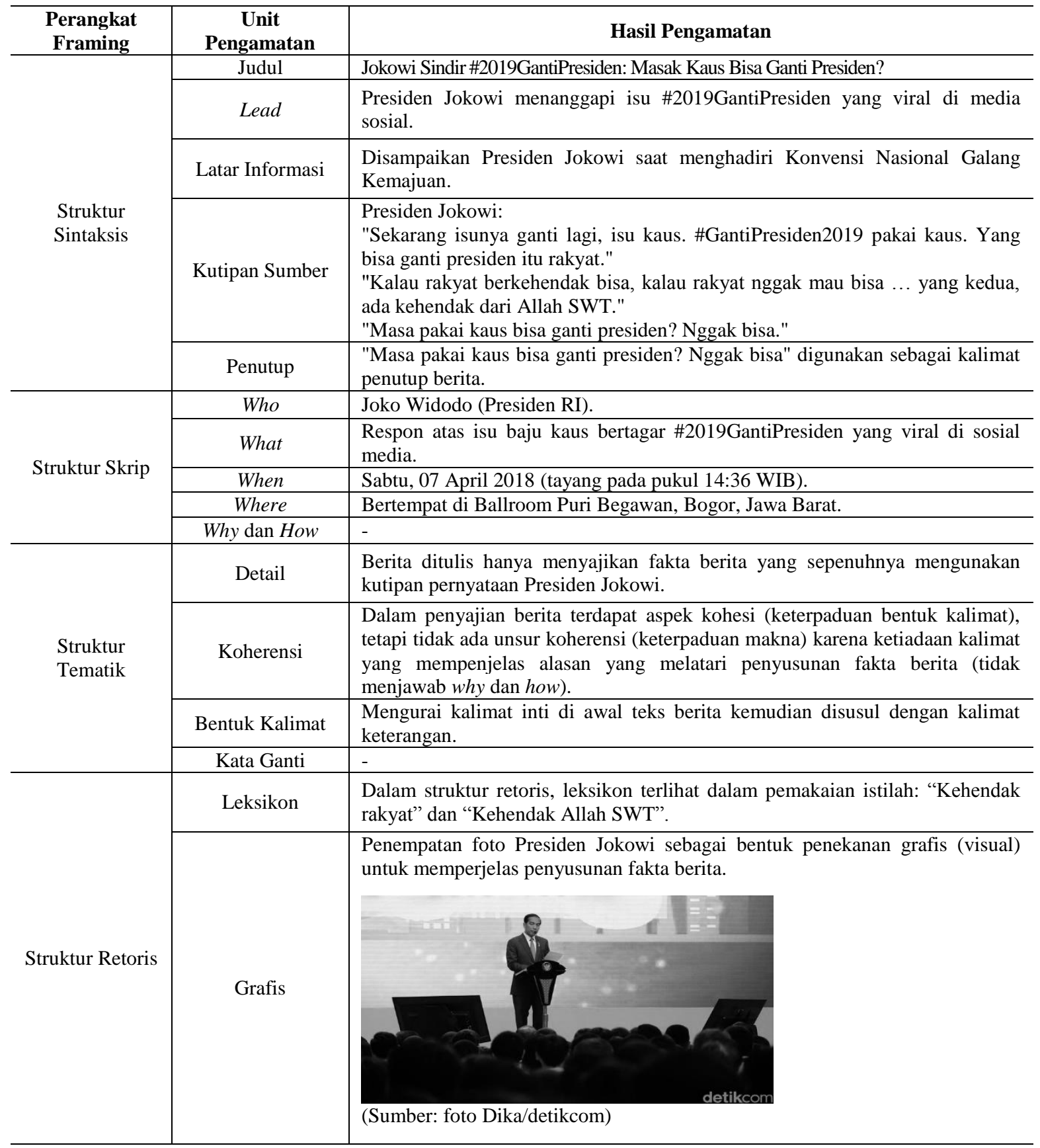




\begin{tabular}{l|l|l}
\hline & Metafora & $\begin{array}{l}\text { "Masa kaus bisa ganti presiden" digunakan sebagai metafor dalam struktur } \\
\text { retoris berita. }\end{array}$ \\
\hline
\end{tabular}

Pada struktur sintaksis (susunan kata/frase dalam kalimat), judul teks berita "Jokowi Sindir \#2019GantiPresiden: Masak Kaus Bisa Ganti Presiden?" (Sabtu, 07 April 2018, pukul 14:36 WIB) bersifat piramida terbalik (dimulai dengan judul, lead, latar informasi, dan penutup). Judul berita yang diakhiri tanda tanya (?) memberi kesan adanya 'kontroversi' pada makna kalimat judul. Judul berita (dengan lead dan kutipan langsung statement presiden) sepertinya dikonstruksi Detik.com untuk empat tujuan: (1) ada unsur 'kontroversi' berita; (2) memenuhi aspek nilai penting berita; (3) menjawab aspek aktualitas berita; dan (4) memenuhi dimensi 'politis' berita.

Judul berita potensial mengarahkan opini, persepsi, dan emosi publik untuk masuk ke wilayah 'pertarungan politik wacana'. Statement presiden "sekarang isunya ganti lagi, isu kaus. \#GantiPresiden2019 pakai kaus" dilanjutkan dengan "masa pakai kaus bisa ganti presiden? Nggak bisa", dan ditutup dengan kalimat "yang bisa ganti presiden itu rakyat." Rangkaian kalimat ini menunjukkan adanya unsur kepentingan Detik.com dalam framing berita karena menonjolkan sisi emosionalnya presiden saat menyikapi tagar (\#)2019GantiPresiden.

Pada struktur skrip (penyusunan fakta berita), narasi berita Detik.com tidak menyertakan aktor lain selain Presiden Joko Widodo yang bisa digunakan sebagai pembanding dalam penyusunan fakta berita. Ditinjau dari sisi komunikasi tekstual dan gaya penulisan berita, alur narasi berita Detik.com bersifat monologis. Sementara ditinjau dari sisi wacana, narasi berita menunjukkan aspek pemaknaan isu \#2019GantiPresiden oleh presiden sebagai bentuk penyataan egatif. Berikutnya, ditinjau dari sisi semiotik, pada teks berita tersirat ada unsur 'penandaan' guna kepentingan penggiringan simbol opini berita.

Pada struktur tematik, konstruksi berita Detik.com tampaknya ditujukan untuk melakukan uji hipotesis terkait informasi adanya 'kegusaran' dalam diri presiden sebagai dampak viralnya \#2019GantiPresiden di media sosial (efek psiko politik). Penempatan presiden sebagai satu-satunya sumber berita-yang statement-nya dikutip dalam bentuk kalimat-kalimat pendek/keterangan; bukan kalimat inti-menjelaskan asumsi itu, yakni ada nilai 'kontroversi' yang melatari motif penulisan berita. Dalam penyusunan fakta berita, Detik.com juga tidak menyertakan aspek koherensi untuk memperjelas alasan mengapa (why) dan bagaimana (how) hingga presiden terkesan bersikap reaktif dalam merespon isu \#2019GantiPresiden.

Pada struktur retoris, Detik.com menggunakan kata yang memberi penekanan pada kalimat "kehendak rakyat" dan "kehendak Allah SWT" sebagai leksikon, serta kalimat "masa kaus bisa ganti presiden" sebagai metafor pada kalimat penutup. Kata "kehendak rakyat" dan "kehendak Allah SWT" di satu sisi bisa ditafsirkan sebagai bentuk ekspresi berpikir 'konstitusional-religius' presiden, namun di sisi lain juga bisa ditafsirkan sebagai bentuk 'ketakutan' presiden dalam merespon isu \#2019GantiPresiden.

Jika ditinjau dalam konsep framing Pan-Kosicki, penyusunan fakta berita Detik.com ("Jokowi Sindir \#2019GantiPresiden: Masak Kaus Bisa Ganti Presiden?") sepertinya bertujuan menggiring opini pembaca ke arah penilaian negatif terhadap presiden (yang bersikap reaktif dan arogan) dalam merespons isu \#2019GantiPresiden.

Tabel 4. Framing Berita Detik.com (Teks Berita 2) Judul: "Relawan \#2019GantiPresiden Bacakan Aspirasi Nasional, Ini Isinya”

\begin{tabular}{|c|c|c|}
\hline $\begin{array}{l}\text { Perangkat } \\
\text { Framing }\end{array}$ & $\begin{array}{c}\text { Unit } \\
\text { Pengamatan } \\
\end{array}$ & Hasil Pengamatan \\
\hline \multirow[b]{3}{*}{$\begin{array}{l}\text { Struktur } \\
\text { Sintaksis }\end{array}$} & Judul & Relawan “\#2019GantiPresiden Bacakan Aspirasi Nasional, Ini Isinya. \\
\hline & Lead & $\begin{array}{l}\text { Deklarasi relawan \#2019GantiPresiden tak hanya membagikan buku pedoman } \\
\text { atau buku manual ke para relawan. Mereka juga membacakan aspirasi yang } \\
\text { intinya menyatakan siap mengawal jalannya Pemilu } 2019 \text { agar berjalan tertib } \\
\text { dan lancar. }\end{array}$ \\
\hline & Latar Informasi & $\begin{array}{l}\text { Pernyataan Relawan \#2019GantiPresiden (Kawasan Patung Kuda, Monas, } \\
\text { Jakarta Pusat). }\end{array}$ \\
\hline
\end{tabular}




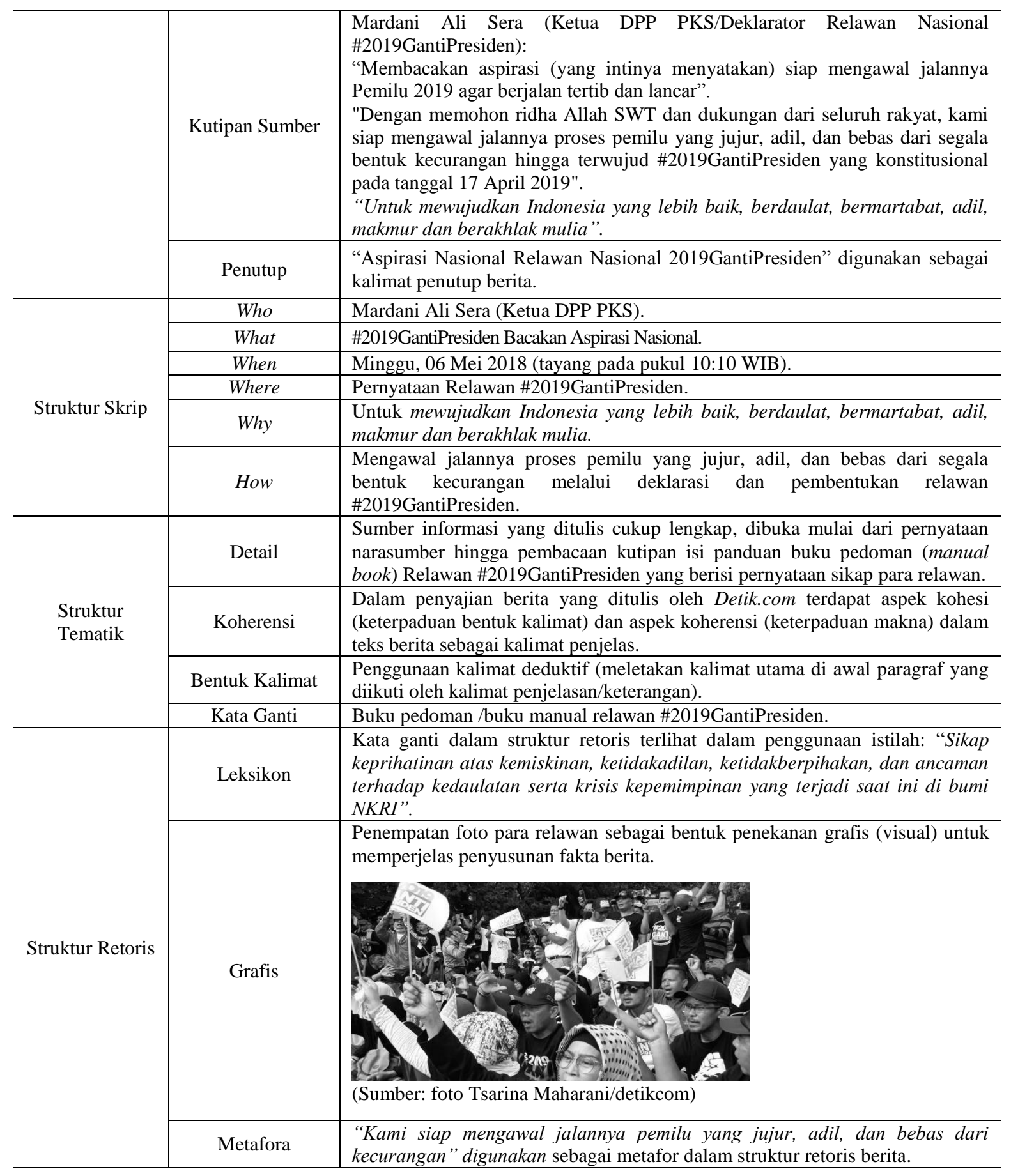

Pada struktur sintaksis (susunan kata/frase dalam kalimat), judul teks berita "Relawan “\#2019GantiPresiden Bacakan Aspirasi Nasional, Ini Isinya" (Minggu, 06 Mei 2018, pukul 10:10 WIB) bersifat straight news karena Detik.com ingin membawa langsung khalayak pembaca masuk ke inti narasi berita (headline) secara cepat. Dari judul berita (Relawan \#2019GantiPresiden Bacakan Aspirasi Nasional, Ini Isinya) terlihat kepentingan Detik.com untuk mengonstruksi kegiatan deklarasi relawan \#2019GantiPresiden sebagai isu utama. Judul berita (dengan lead dan kutipan langsung dari Ali Sera selaku tokoh PKS, tokoh oposisi dan tim sukses pasangan Prabowo-Sandi) dikutip Detik.com untuk memberi tekanan pada nilai penting berita, aktualitas berita, dan dimensi 'politis' berita.

Judul berita potensial mengarahkan opini publik untuk mengetahui aksi deklarasi relawan \#2019GantiPresiden. Statement Ali Sera selaku deklarator/jurubicara ("siap mengawal jalannya pemilu 2019 agar berjalan tertib dan lancar", disambung dengan kalimat "dengan memohon ridha 
Allah SWT dan dukungan dari seluruh rakyat, kami siap mengawal jalannya proses pemilu yang jujur, adil, dan bebas dari segala bentuk kecurangan hingga terwujud \#2019GantiPresiden yang konstitusional pada tanggal 17 April 2019"), jelas dilatari oleh motif curiga terkait netralitas pemerintah dalam pelaksanaan pemilu 2019. Kutipan pernyataan Ali Sera yang dikonstruksi Detik.com menunjukkan adanya unsur framing (penonjolan) 'potensi kecurangan' yang akan dilakukan Jokowi dalam pemilu. Untuk itu, relawan \#2019GantiPresiden meminta dukungan rakyat untuk mengawal pemilu 2019 sebagai kondisi mendesak yang digunakan sebagai inti berita.

Pada struktur skrip, narasi berita Detik.com tidak menyertakan narasumber lain selain Ali Sera sehingga opini Ali Sera menjadi satu-satunya rujukan dalam penyusunan fakta berita. Ditinjau dari sisi komunikasi, alur narasi Detik.com bersifat monologis. Sementara ditinjau dari sisi wacana, narasi berita Detik.com tampak lebih menonjolkan kepentingan relawan \#2019GantiPresiden sebagai isu dominan. Statement Ali Sera juga disusun sebagai fakta berita yang memberi framing positif pada dirinya selaku tokoh oposisi sekaligus deklarator relawan \#2019GantiPresiden.

Pada struktur tematik, konstruksi berita Detik.com ditujukan untuk memberi legitimasi atas isu \#2019GantiPresiden. Penempatan Ali Sera sebagai narasumber tunggal-yang pernyataannya dikutip dalam bentuk kalimat inti/lengkap - memberi indikasi penonjolan (framing) berita. Buku pedoman juga digunakan sebagai kata ganti untuk menyamarkan tujuan 'politis' deklarasi. Dalam menyusun fakta berita, Detik.com juga menyertakan aspek kohesi dan koherensi untuk memperjelas alasan why ("terselenggaranya pemilu 2019 yang jujur, adil, dan bebas dari segala bentuk kecurangan") dan how ("terwujudnya Indonesia yang lebih baik, berdaulat, bermartabat, adil, makmur dan berakhlak mulia").

Pada struktur retoris, Detik.com memberi penonjolan pada kalimat "dengan memohon ridha Allah SWT dan dukungan dari seluruh rakyat" serta kalimat "sikap keprihatinan atas kemiskinan, ketidakadilan, ketidakberpihakan, dan ancaman terhadap kedaulatan serta krisis kepemimpinan yang terjadi saat ini di bumi NKRI'. Konstruksi kalimat seperti ini bisa ditafsirkan khalyak sebagai bentuk 'keprihatinan' relawan pendukung \#2019GantiPresiden atas kualitas pelaksanaan pemilu 2019 yang potensial berlangsung tidak jurdil dan penuh kecurangan.

Tabel 5. Framing Berita Kompas.com (Teks Berita 3)

Judul: "Muncul Tagar \#2019GantiPresiden, PPP Usul Tagar \#Lanjutkan212"

\begin{tabular}{|c|c|c|}
\hline $\begin{array}{l}\text { Perangkat } \\
\text { Framing }\end{array}$ & $\begin{array}{c}\text { Unit } \\
\text { Pengamatan } \\
\end{array}$ & Hasil Pengamatan \\
\hline \multirow{5}{*}{$\begin{array}{l}\text { Struktur } \\
\text { Sintaksis }\end{array}$} & Judul & Muncul Tagar \#2019GantiPresiden, PPP Usul Tagar \#Lanjutkan212. \\
\hline & Lead & Polemik isu \#2019GantiPresiden. \\
\hline & Latar Informasi & $\begin{array}{l}\text { Kemunculan tagar (\#)2019GantiPresiden yang viral di jejaring lini massa } \\
\text { media sosial versus tagar (\#)Lanjutkan2112. }\end{array}$ \\
\hline & Kutipan Sumber & $\begin{array}{l}\text { Romahurmuziy (Ketua Umum PPP): } \\
\text { "Tak ambil pusing dengan kemunculan tagar \#2019GantiPresiden di media } \\
\text { sosial yang menginginkan agar Presiden Joko Widodo tak terpilih kembali". } \\
\text { "Pertarungan } 2019 \text { itu sudah menuju pada bipolarisasi dua kutub saja, jadi pasti } \\
\text { yang melontarkan hashtag itu adalah lawan politik Pak Jokowi dan itu hal yang } \\
\text { biasa dalam demokrasi". "\#Lanjutkan212, karena Pak Jokowi sudah dua } \\
\text { periode memimpin kota Solo, satu periode jadi Gubernur DKI Jakarta dan hari } \\
\text { ini, Insya Allah dua periode sebagai presiden, saya kira itu". } \\
\text { Mardani Ali Sera (Ketua DPP PKS): } \\
\text { "Gerakan \#2019GantiPresiden adalah gerakan yang sah, legal dan } \\
\text { konstitusional. Konstitusi kita di Pasal 22E menegaskan bahwa pemilu } \\
\text { diselenggarakan tiap } 5 \text { tahun untuk memilih, salah satunya (memilih) Presiden } \\
\text { dan Wakil Presiden". }\end{array}$ \\
\hline & Penutup & $\begin{array}{l}\text { "Tagar \#2019GantiPresiden merupakan antitesa dari kampanye 'dua periode' } \\
\text { yang digaungkan oleh kelompok pendukung Jokowi di media sosial". }\end{array}$ \\
\hline \multirow{4}{*}{ Struktur Skrip } & Who & $\begin{array}{l}\text { Romahurmuziy (Ketua Umum PPP) } \\
\text { Mardani Ali Sera (Ketua DPP PKS). }\end{array}$ \\
\hline & What & Perang tagar (\#)2019GantiPresiden versus \#Lanjutkan 212. \\
\hline & When & Rabu, 04 April 2018 (tayang pada pukul 18:18) \\
\hline & Where & Kompleks Parlemen (Gedung DPR/DPD RI), Senayan. \\
\hline
\end{tabular}




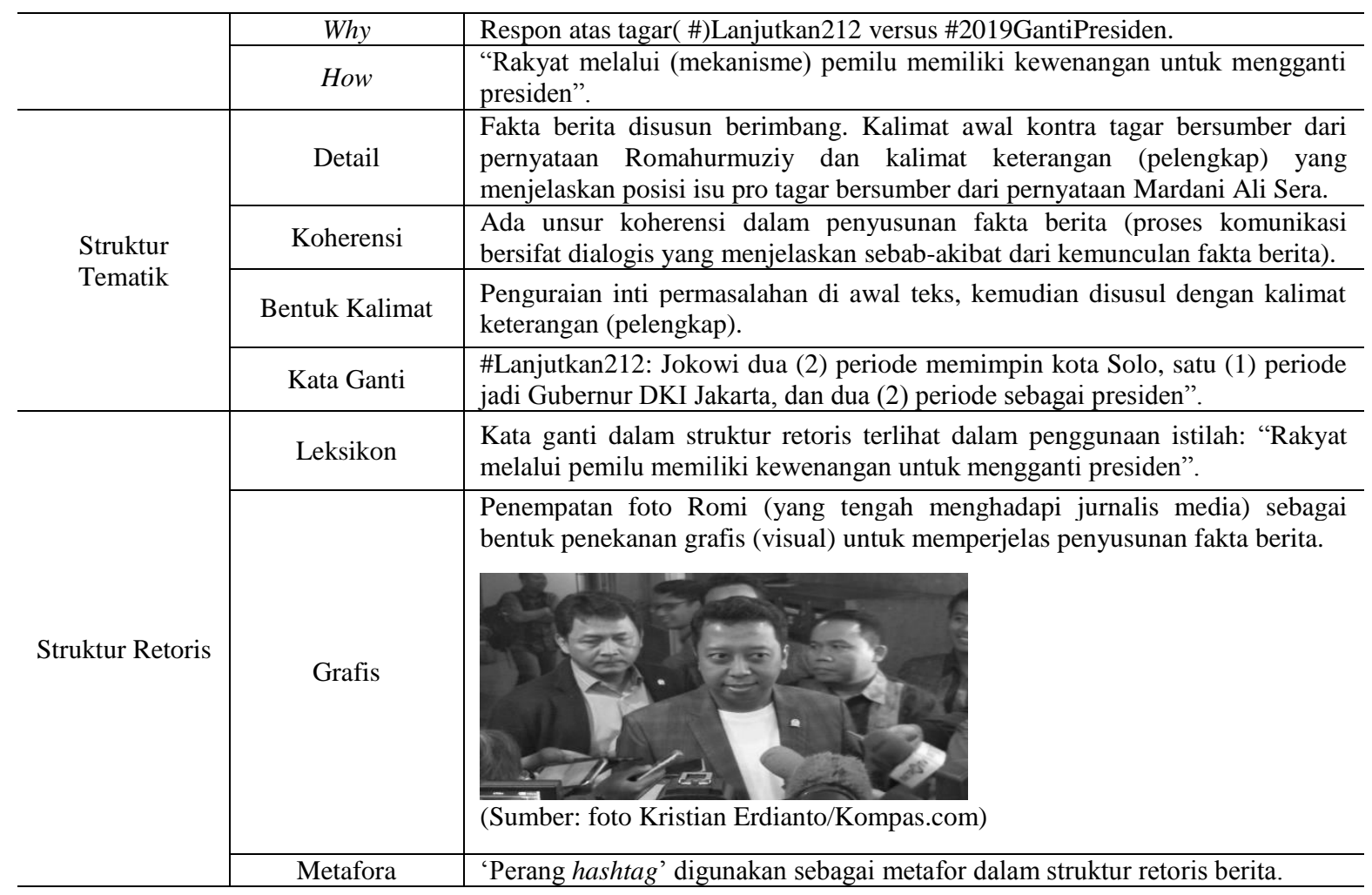

Pada struktur sintaksis (susunan kata/frase dalam kalimat), judul teks berita "Muncul Tagar \#2019GantiPresiden, PPP Usul Tagar \#Lanjutkan212" (Rabu, 04 April 2018, pukul 18:18) disusun dengan menggunakan teknik penulisan piramida terbalik. Dari judul berita terlihat kepentingan Kompas.com untuk mengonstruksi kemunculan tagar (\#)2019GantiPresiden sebagai isu yang penting bagi publik (public concern). Penyusunan fakta berita dilakukan dengan mengambil lead berita dan kutipan langsung dari dua tokoh parpol ternama (Romahurmuziy alias Romi dan Ali Sera-yang selama ini dikenal publik sebagai dua tokoh yang bersebrangan secara politik: Romi pro Jokowi, Ali Sera kontra Jokowi). Pernyataan kedua tokoh politik yang berposisi 'antagonis' itu dijadikan kutipan sebagai latar berita untuk menunjukkan causal reasioning pada khalayak terkait isu pilpres 2019 yang saat itu menjadi perdebatan hangat media (public discourse). Target isu pilpres (melalui perang hashtag) yang memiliki nilai penting berita, nilai aktualitas berita, dan nilai 'politis' berita sepertinya telah tercapai dalam framing berita.

Judul berita Kompas.com sepertinya ingin mengarahkan opini atau persepsi publik agar terlibat langsung dalam perang tagar \#2019GantiPresiden versus \#Lanjutkan212. Dengan mengutip statement Romi "tak ambil pusing dengan kemunculan tagar \#2019GantiPresiden di media sosial yang menginginkan agar Presiden Joko Widodo tak terpilih kembali" (K1), dilanjutkan dengan kalimat "pertarungan 2019 itu sudah menuju pada bipolarisasi dua kutub saja, jadi pasti yang melontarkan hashtag itu adalah lawan politik Pak Jokowi dan itu hal yang biasa dalam demokrasi" (K2), serta ditutup dengan kalimat "\#Lanjutkan212, karena Pak Jokowi sudah dua periode memimpin kota Solo, satu periode jadi Gubernur DKI Jakarta dan hari ini, Insya Allah dua periode sebagai presiden, saya kira itu" (K3); 'perang hastag' sepertinya telah terkonstruksi dan memenuhi unsur 'kontroversi' berita.

Ketiga rangkaian pernyataan Romi di atas, dari konteks makna bahasa, bisa dimaknai sebagai: merepresentasikan sikap 'gusar' dan 'panik' kelompok pro Jokowi melihat derasnya isu \#2019GantiPresiden yang viral di sosial media (K1); merepresentasikan sikap 'reaktif' melalui statement negatif Romi bahwa hashtag bertentangan dengan prinsip demokrasi (K3); merepresentasikan sikap 'perlawanan' kelompok pro Jokowi untuk tetap bersikap 'optimis' untuk melanjutkan kekuasaan Presiden Jokowi untuk periode kedua (2019-2024) (K2). 
Ali Sera menyatakan bahwa "Gerakan \#2019GantiPresiden adalah gerakan yang sah, legal dan konstitusional. Konstitusi kita di Pasal 22E menegaskan bahwa pemilu diselenggarakan tiap 5 tahun untuk memilih, salah satunya (memilih) Presiden dan Wakil Presiden". Pernyataan ini menunjukkan counter discourse atas wacana \#Lanjutkan212 kelompok pro Jokowi (seperti disampaikan Romi). Secara simbolik, kelompok pro Jokowi merasa 'terganggu' dengan tagar \#2019GantiPresiden (yang kian viral) dan memberi tekanan pada perang tagar sebagai bentuk kampanye negatif di alam demokrasi.

Kutipan sumber Kompas.com menunjukkan adanya penyusunan fakta berita yang berimbang antara narasumber pro wacana (tagar \#2019GantiPresiden) versus narasumber anti wacana (tagar \#Lanjutkan212). Namun, penyusunan fakta berita dengan menempatkan statement Ali Sera di akhir berita merupakan penonjolan kalimat positif Kompas.com pada kelompok pro \#2019GantiPresiden (dalam framing, penonjolan biasa digunakan di awal atau di akhir kalimat).

Pada struktur skrip, narasi berita Kompas.com telah memenuhi unsur keseimbangan berita (element of news balance) dengan mengutip pernyataan dua narsumber yang statement-nya dijadikan dasar dalam penyusunan fakta berita. Ditinjau dari sisi komunikasi, alur narasi dalam berita Kompas.com bersifat dialogis. Ditinjau dari sisi wacana, narasi berita Kompas.com tampak lebih menonjolkan sisi kepentingan politik kelompok pendukung \#2019GantiPresiden yang digunakan sebagai sikap kontra wacana (counter discourse). Statement Ali Sera sepertinya juga ditempatkan dalam makna yang relatif positif (dari sisi politis) sebagai representasi kelompok oposisi yang menginisiasi dan melegitimasi proses perluasaan (eksternalisasi) wacana tagar (\#)2019GantiPresiden.

Pada struktur tematik, konstruksi berita Kompas.com kian meneguhkan asumsi adanya 'perang tagar' yang bias dan subjektif. Kutipan pernyataan Romi dan Ali Sera menunjukkan bukti kuat bahwa penyusunan fakta berita Kompas.com tertuju pada isu perang tagar sebagai wacana dominan yang eksesif dan kumulatif. Dalam menyusun fakta berita, Kompas.com juga menyertakan aspek kohesi dan koherensi untuk memperjelas alasan why ("respon atas wacana \#2019GantiPresiden") dan how ("\#Lanjutkan212: [karena] Jokowi [telah] dua periode memimpin kota Solo, satu periode jadi Gubernur DKI Jakarta, dan dua periode sebagai presiden”).

Pada struktur retoris, Kompas.com menggunakan metafor 'perang tagar', memberi tekanan pada kata ganti ("rakyat melalui pemilu memiliki kewenangan untuk mengganti presiden"), serta penempatan foto Romi dalam teks berita sebagai bentuk penekanan grafis (visual) pada fakta berita. Penempatan metafor dan grafis yang dipadukan dengan kata ganti pada struktur berita Kompas.com diarahkan untuk dua tujuan: (1) penguatan isu perang wacara antara tagar \#2019GantiPresiden versus \#Lanjutkan212; dan (2) memberi ruang lebih luas pada wacana \#2019GantiPresiden yang diinisiasi oleh kelompok pro tagar sebagai wacana tandingan (counter discourse).

Tabel 6. Framing Berita Kompas.com (Teks Berita 4)

Judul: "Sejumlah Anak Turut Kenakan Kaus \#2019GantiPresiden di CFD"

\begin{tabular}{|c|c|c|}
\hline $\begin{array}{l}\text { Perangkat } \\
\text { Framing }\end{array}$ & $\begin{array}{c}\text { Unit } \\
\text { Pengamatan }\end{array}$ & Hasil Pengamatan \\
\hline \multirow{5}{*}{$\begin{array}{l}\text { Struktur } \\
\text { Sintaksis }\end{array}$} & Judul & Sejumlah Anak Turut Kenakan Kaus \#2019GantiPresiden di CFD. \\
\hline & Lead & $\begin{array}{l}\text { Sejumlah anak terpantau menggunakan kaus \#2019GantiPresiden di acara car } \\
\text { free day (CFD). }\end{array}$ \\
\hline & Latar Informasi & $\begin{array}{l}\text { Ada indikasi pelanggaran yang menyertakan anak di bawah umur memakai } \\
\text { kaus \#2019GantiPresiden. }\end{array}$ \\
\hline & Kutipan Sumber & $\begin{array}{l}\text { Mardani Ali Sera (Ketua DPP PKS): } \\
\text { "Memastikan (acara) deklarasi \#2019GantiPresiden yang rencananya akan } \\
\text { digelar di kawasan Patung Kuda, Jakarta Pusat telah mengantongi izin polisi". } \\
\text { Kombes Pol. Argo Juwono (Kabid Humas Polda Metro Jaya): } \\
\text { "Hari ini ada kegiatannya (deklarasi \#2019GantiPresiden) dan sudah disiapkan } \\
\text { pengamanannya". }\end{array}$ \\
\hline & Penutup & Polri sudah menyiapkan pengamanan kegiatan deklarasi. \\
\hline
\end{tabular}




\begin{tabular}{|c|c|c|}
\hline \multirow{6}{*}{ Struktur Skrip } & Who & $\begin{array}{l}\text { Mardani Ali Sera (Ketua DPP PKS) } \\
\text { Kombes Pol. Argo Juwono (Kabid Humas Polda Metro Jaya) }\end{array}$ \\
\hline & What & Rencana acara Deklarasi Relawan \#2019GantiPresiden. \\
\hline & When & Minggu, 06 Mei 2018 (tayang pukul 11:18). \\
\hline & Where & Car Free Day/CFD (Hari Bebas Kendaraan Bermotor). \\
\hline & Why & $\begin{array}{lccccc}\text { Antisipasi Polri atas } & \text { rencana } & \text { penyelenggaraan } & \text { acara } & \text { deklarasi } \\
\text { \#2012GantiPresiden. }\end{array}$ \\
\hline & How & $\begin{array}{l}\text { Mempersiapkan pengamanan rencana penyelenggaraan acara deklarasi } \\
\text { \#2012GantiPresiden. }\end{array}$ \\
\hline \multirow{4}{*}{$\begin{array}{l}\text { Struktur } \\
\text { Tematik }\end{array}$} & Detail & $\begin{array}{l}\text { Penulisan fakta berita bersifat penjelasan (wartawan menjelaskan hasil } \\
\text { pantauan lapangan). }\end{array}$ \\
\hline & Koherensi & $\begin{array}{l}\text { Tidak unsur koherensi dalam penyusunan fakta berita (proses komunikasi } \\
\text { bersifat monologis, tidak menjelaskan sebab-akibat dari permasalahan yang } \\
\text { dimunculkan sebagai fakta berita). }\end{array}$ \\
\hline & Bentuk Kalimat & $\begin{array}{l}\text { Penguraian inti fakta berita di awal teks, kemudian disusul dengan kalimat } \\
\text { keterangan (pelengkap). }\end{array}$ \\
\hline & Kata Ganti & Apakah acara ini telah mendapat izin dari kepolisian atau belum? \\
\hline \multirow{4}{*}{ Struktur Retoris } & Leksikon & $\begin{array}{l}\text { Ada penonjolan isu yang penekanannya dalam teks berita, seperti kata } \\
\text { sejumlah anak dan keluarganya serta para pedagang yang terlihat mengenakan } \\
\text { dan menjual kaus \#2019GantiPresiden di lokasi acara care free day (CFD). }\end{array}$ \\
\hline & \multirow[b]{2}{*}{ Grafis } & $\begin{array}{l}\text { Penempatan foto peserta care free day; angle foto diarahkan pada seorang } \\
\text { peserta (anak di bawah umur - dengan wajah di blur - yang mengenakan kaus } \\
\text { \#2019GantiPresiden) sebagai bentuk penekanan grafis (visual) untuk } \\
\text { memperjelas penyusunan fakta berita. }\end{array}$ \\
\hline & & \\
\hline & Metafora & $\begin{array}{l}\text { Telah mengantongi izin polisi digunakan sebagai metafor dalam struktur retoris } \\
\text { berita. }\end{array}$ \\
\hline
\end{tabular}

Pada struktur sintaksis (susunan kata/frase dalam kalimat), judul teks berita "Sejumlah Anak Turut Kenakan Kaus \#2019GantiPresiden di CFD" (Rabu, 06 Mei 2018, pukul 11:18) disusun melalui teknik penulisan piramida terbalik. Dari judul berita terlihat framing Kompas.com untuk mengonstruksi adanya indikasi: (1) penggunaan kaus/atribut tagar (\#)2019GantiPresiden di acara CFD; (2) pelibatan anak di bawah umur yang menggunakan kaus bertagar (\#)2019Ganti Presiden di acara CFD; dan (3) penjualan kaus/atribut bertagar (\#)2019GantiPresiden di lokasi CFD.

Penyusunan fakta berita sebagai informasi penting bagi publik dilakukan dengan mengambil lead berita dari kutipan langsung statement Ali Sera (Ketua DPP PKS) dan Kombes Pol. Argo Yuwono (Kabid Humas Polda Metro Jaya). Pernyataan dua narasumber sesungguhnya tidak terkait langsung dengan fakta berita, tetapi tetap dijadikan causal reasoning dalam penulisan latar berita sebagai strategi untuk menunjukkan fakta 'pelanggaran hukum' yang dilakukan kelompok massa pro \#2019GantiPresiden di acara CFD. Target yang ingin dicapai dari narasi berita Kompas.com adalah mem-framing aspek 'pelanggaran hukum' kelompok massa pro tagar dilokasi CFD sebagai nilai penting berita, nilai aktualitas berita, dan nilai politis berita.

Judul berita Kompas.com sepertinya diarahkan untuk membangun opini/persepsi publik agar pelanggaran yang dilakukan kelompok pro \#2019GantiPresiden merupakan fakta berita (menjadi konsensus sosial). Padahal kutipan narasumber yang dijadikan latar dalam penyusunan fakta berita, seperti "memastikan (acara) deklarasi \#2019GantiPresiden yang rencananya akan digelar di kawasan Patung Kuda, Jakarta Pusat telah mengantongi izin polisi" (yang dikutip dari pernyataan Ali Sera/Ketua DPP PKS) atau kalimat "hari ini ada kegiatannya (deklarasi \#2019GantiPresiden) dan sudah disiapkan pengamanannya" (yang dikutip dari pernyataan Kombes Pol. Argo 
Juwono/Kabid Humas Polda Metro Jaya) jelas tidak menunjukkan adanya hubungan (konjungsi), keterkaitan bentuk berita (kohesi), dan relasi makna wacana berita (koherensi).

Pada struktur skrip, narasi berita Kompas.com memenuhi unsur news equality karena mendasari penyusunan fakta berita dengan mengutip pernyataan dua narsumber berita. Namun, statement narasumber yang dijadikan rujukan tidak memenuhi unsur kohesi, koherensi, dan konjungsi berita. Ada kandungan subjektivitas dalam penyusunan fakta berita. Fakta berita yang disusun terkesan memaksakan judul berita agar terkesan memenuhi unsur kohesi, koherensi, dan konjungsi pada lead berita, latar informasi berita, dan sumber kutipan berita. Ditinjau dari sisi komunikasi, alur narasi dalam penyusunan fakta berita bersifat subjektif (bias atau berpihak). Dan ditinjau dari sisi wacana, narasi berita Kompas.com lebih menonjolkan aspek 'pelanggaran hukum' yang ditujukan pada kelompok massa pro tagar sebagai kelompok 'pelanggar hukum'.

Pada struktur tematik, framing berita Kompas.com memperkuat asumsi kelompok massa pro tagar sebagai 'pelanggar hukum' karena penyusun fakta berita tidak mempertimbangkan causal reasionong, yakni terpenuhinya aspek konjungsi (keterhubungan kalimat), kohesi (keterkaitan bentuk kalimat), dan koherensi (kesesuaian makna kalimat dalam berita) untuk membuktikan why dan how (atas dasar apa dan dengan standar prosedur seperti apa Polri melakukan antisipasi atas rencana penyelenggaraan acara deklarasi \#2012GantiPresiden yang dijamin konstitusi).

Pada struktur retoris, Kompas.com menggunakan metafor 'telah mengantongi izin polisi' dan memberi tekanan pada kata ganti "apakah acara ini telah mendapat izin dari kepolisian atau belum?". Leksikon berita juga memberi penonjolan: "ada sejumlah anak dan keluarganya serta para pedagang yang terlihat mengenakan dan menjual kaus \#2019GantiPresiden di lokasi acara CFD" serta foto "sejumlah peserta CFD yang menggunakan kaus \#2019GantiPresiden" untuk memberi penekanan grafis (visual) pada fakta berita yang menjadi tujuan utama framing berita.

Penempatan kalimat metafor dan foto (aspek grafis/visual) yang dipadukan dengan penempatan kata ganti ("apakah acara ini telah mendapat izin kepolisian?") dan leksikon ("ada sejumlah anak dan keluarganya serta para pedagang yang terlihat mengenakan dan menjual kaus \#2019GantiPresiden di lokasi acara CFD”) menunjukkan indikasi framing negatif pemberitaan Kompas.com. Tujuan pemberitaan adalah mengonstruksi counter discourse guna mendelegitimasi aspek moral kelompok massa pendukung \#2019GantiPresiden sebagai entitas 'pelanggar hukum'.

Mengacu pada hasil pemaparan, analisis, dan interpretasi keempat teks berita di atas, tabel 7 di bawah disusun sebagai komparasi untuk melihat letak aspek subjektivitas kekuasaan yang identifikasinya dapat ditemukan dari ada tidaknya pemenuhan aspek kausalitas (causal reasoning) dalam proses penyusunan fakta berita di kedua portal berita online yang menjadi objek analisis.

Tabel 7. Komparasi subjektivitas kekuasaan (Causal Reasioning) dalam pemberitaan Detik.com dan Kompas.com

\begin{tabular}{|c|c|}
\hline \multicolumn{2}{|c|}{ Elemen Sintaksis } \\
\hline Detik.com & Kompas.com \\
\hline $\begin{array}{l}\text { Teks Berita 1: "Jokowi Sindir \#2019GantiPresiden: Masak Kaus } \\
\text { Bisa Ganti Presiden?" }\end{array}$ & $\begin{array}{l}\text { Teks Berita 3: "Muncul Tagar \#2019Ganti Presiden, PPP } \\
\text { Usul Tagar \#Lanjutkan212" }\end{array}$ \\
\hline $\begin{array}{l}\text { - Penyusunan judul berita bersifat 'kontroversi' } \\
\text { (menggunakan tanda tanya [?] pada judul berita). } \\
\text { - Penyusunan fakta berita menggunakan teknik penulisan } \\
\text { piramida terbalik. } \\
\text { - Memberi atribusi 'panik' pada gimmick presiden dalam } \\
\text { menghadapi isu/wacana \#2019GantiPresiden. } \\
\text { - Membuka ruang diskusi dan edukasi politik pada publik } \\
\text { terkait isu \#2019GantiPresiden sebagai medan } \\
\text { pertarungan wacana. } \\
\text { - Memberi apresiasi (dukungan simbolik) pada gerakan } \\
\text { \#2019GantiPresiden. }\end{array}$ & $\begin{array}{l}\text { - Penyusunan judul berita bersifat 'kontradiktif'. } \\
\text { - Penyusunan fakta berita menggunakan teknik penulisan } \\
\text { piramida terbalik. } \\
\text { - Memberi atribusi 'antagonis' pada sumber kutipan berita. } \\
\text { - Membuka ruang diskusi dan edukasi politik pada publik } \\
\text { terkait isu \#2019GantiPresiden versus \#Lanjutkan212 } \\
\text { sebagai medan pertarungan wacana. } \\
\text { - Memberi apresiasi pada masing-masing pendukung tagar } \\
\text { (\#2019GantiPresiden versus \#Lanjutkan212). }\end{array}$ \\
\hline \multicolumn{2}{|c|}{ Elemen Skrip } \\
\hline $\begin{array}{l}\text { - Presiden diposisikan sebagai aktor tunggal yang } \\
\text { mendominasi penulisan berita. } \\
\text { - Pernyataan presiden digunakan sebagai fakta berita. }\end{array}$ & $\begin{array}{l}\text { - Mardani dan Romi diposisikan secara seimbang dalam } \\
\text { penulisan fakta berita. } \\
\text { - Pernyataan kedua narasumber digunakan sebagai fakta }\end{array}$ \\
\hline
\end{tabular}




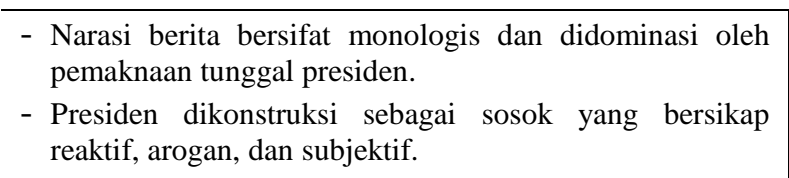

berita.

- Narasi berita bersifat dialogis (kelompok pro tagar versus kontra-tagar).

- Mardani dikonstruksi positif, sedangkan Romi dikonstruksi relatif negatif.

\section{Elemen Tematik}

- Ada aspek kontroversi dalam judul berita.

- Ada aspek kontroversi dalam judul berita.

- Tidak ada aspek koherensi dalam penulisan fakta berita (berita ditulis dalam bentuk kalimat pendek/keterangan).

- Tidak menjawab aspek why dan how sebagai fakta yang melatari penulisan berita.

- Ada aspek koherensi dan kohesi dalam penulisan fakta berita (berita ditulis dalam bentuk kalimat inti/lengkap).

- Menjawab aspek why dan how yang melatari fakta berita.

\section{Elemen Retoris}

- Menggunakan leksikon bermakna ganda.

- Menggunan kalimat penutup yang bernada 'menyindir'.

- Penempatan foto Presiden Jokowi untuk memperjelas fakta berita.

- Ada fakta framing negatif terhadap presiden (reaktif, arogan, dan subjektif) terkait respon presiden atas \#2019GantiPresiden.

- Menggunakan leksikon bermakna normatif.

- Menggunakan kalimat penutup 'konfliktual' antar kelompok pendukung versus kelompok anti tagar.

- Penempatan foto Romi untuk memperjelas fakta berita.

- Ada fakta framing positif, berupa pembukaan ruang dialog terkait wacana perang tagar sebagai isu penting dan strategis.

\section{Elemen Sintaksis}

Teks Berita 2: "Relawan \#2019GantiPresiden Bacakan Aspirasi Nasional, Ini Isinya"

- Penyusunan fakta berita menggunakan teknik penulisan straight news.

- Memberi atribusi 'positif' pada acara deklarasi relawan nasional \#2019GantiPresiden, dan makna ajakan pada publik untuk ikut terlibat dalam medan wacana (field of discourse) tagar (\#)2019GantiPresiden (unsur edukasi politik).

- Kecurigaan terkait netralitas pemerintahan Joko Widodo dalam penyelenggaraan pemilu 2019 yang jurdil dan bebas dari kecurangan.

- Makna positif pada statement Mardani Ali Sera (selaku juru bicara relawan/deklarator acara \#2019GantiPresiden). Elemen Sk

Teks Berita 4: "Sejumlah Anak Turut Kenakan Kaus \#2019GantiPresiden di CFD"

- Penyusunan fakta berita menggunakan teknik penulisan piramida terbalik.

- Memberi atribusi 'negatif' pada kelompok masyarakat yang menggunakan kaus tagar (\#)2019GantiPresiden pada acara CFD.

- Ada aspek pelanggaran hukum (unsur edukasi hukum pemilu pada publik).

- Makna kecurigaan pada kelompok masyarakat pengguna kaus/atribut \#2019GantiPresiden.

- Penggunaan kalimat konjungtif. Tidak ada aspek causal reasioning (alasan logis sebab-akibat) dan tidak ada aspek kohesi serta koherensi dalam penyusunan fakta berita.

\begin{tabular}{|c|c|}
\hline \multicolumn{2}{|c|}{ Elemen Skrip } \\
\hline $\begin{array}{l}\text { - Mardani Ali Sera diposisikan sebagai aktor tunggal yang } \\
\text { mendasari penulisan berita. } \\
\text { - Pernyataan Mardani Ali Sera digunakan sebagai fakta } \\
\text { berita. } \\
\text { - Narasi berita bersifat monologis dan didominasi oleh } \\
\text { pemaknaan tunggal narasumber. } \\
\text { - Pernyataan Mardani Ali Sera dikonstruksi positif. }\end{array}$ & $\begin{array}{l}\text { - Pernyatan narasumber tidak relevan dengan fakta berita. } \\
\text { - Pernyataan kedua narasumber tidak memenuhi aspek } \\
\text { konjungsi, kohesi, dan koherensi berita. } \\
\text { - Narasi berita bersifat subjektif dan didominasi } \\
\text { pemaknaan tunggal wartawan/media. } \\
\text { - Framing negatif terhadap kelompok pro tagar } \\
\text { (\#)2019GantiPresiden. }\end{array}$ \\
\hline
\end{tabular}

\begin{tabular}{|c|c|}
\hline \multicolumn{2}{|c|}{ Struktur Tematik } \\
\hline $\begin{array}{l}\text { - Ada aspek pemberian makna (legitimasi) politis pada isu } \\
\text { \#2019GantiPresiden. } \\
\text { - Ada aspek kohesi dan koherensi dalam susunan fakta } \\
\text { berita. } \\
\text { - Menjawab aspek why dan how. }\end{array}$ & $\begin{array}{l}\text { - Ada aspek legitimasi politis pada kelompok pro tagar } \\
\text { (\#)Lanjutkan212. } \\
\text { - Tidak ada aspek konjungsi, kohesi, dan koherensi dalam } \\
\text { susunan fakta berita. } \\
\text { - Tidak menjawab aspek why dan how. }\end{array}$ \\
\hline \multicolumn{2}{|c|}{ Elemen Retoris } \\
\hline $\begin{array}{l}\text { - Menggunakan leksikon yang bersifat kritik serta metafor } \\
\text { yang idealis-patriotis. } \\
\text { - Penempatan foto relawan \#2019GantiPresiden untuk } \\
\text { memperjelas fakta berita. } \\
\text { - Menggunakan kalimat penutup yang bermakna permisif } \\
\text { (potensi kecurangan pilpres 2019). } \\
\text { - Framing negatif (konotatif) terkait pilpres } 2019 \text { yang } \\
\text { jurdil dan bebas dari kecurangan. }\end{array}$ & $\begin{array}{l}\text { - Menggunakan metafor yang bermakna negatif (kalimat } \\
\text { tanya?). } \\
\text { - Menggunakan leksikon yang bermakna subjektif. } \\
\text { - Penempatan foto peserta CFD pengguna kaus } \\
\text { \#2019GantiPresiden untuk mempertegas fakta berita. } \\
\text { - Framing negatif terhadap peserta CFD pendukung tagar } \\
\text { (\#)2019GantiPresiden. }\end{array}$ \\
\hline
\end{tabular}




\subsection{Diskusi}

Kajian subjektivitas kekuasaan dalam pemberitaan media model analisis framing Pan-Kosicki pada laman Detik.com dan Kompas.com menunjukkan relevansi dengan pemahaman paradigma konstruksi sosial yang memberi penekanan pada praktik bahasa dalam framing berita. Relevansi pertama terlihat saat portal berita Detik.com dan Kompas.com sebagai ruang ekspresi dan aspirasi publik menjadi 'realitas objektif' (objective reality) — kompleksitas rutinitas perilaku dan tindakan yang telah terpola, yang dihayati oleh individu secara umum sebagai fakta sosial—yang tercermin dari maraknya pemberitaan Detik.com dan Kompas.com terkait perang tagar (\#)2019GantiPresiden yang berlangsung intens dan massif sebagai realitas objektif di ruang sosial pemberitaan media.

Relevansi kedua terlihat saat Detik.com menarasikan bahwa tagar (\#)2019GantiPresiden adalah hak demokrasi politik publik yang telah mengalami pemapanan pola, atau tempat tersemainya ekspresi rakyat terhadap simbolitas kekuasaan penting untuk dipertarungkan di pasar wacana media. Tindakan dan perilaku publik yang tercermin dalam ruang demokrasi adalah ekspresi sekaligus hak politik publik terkait penyelenggaraan pilpres 2019 yang jurdil dan luber.

Relevansi ketiga terlihat dari sisi 'realitas simbolik'-yakni semua ekspresi simbolik (tanda, seperti tagar, hastag, narasi, label) yang bersumber dari apa yang dihayati individu atau kelompok sebagai realitas objektif (hasil negosiasi atau konsensus yang bersifat intersubjektif). Ekspresi simbolik dalam tagar (\#)2019GantiPresiden, dimaknai secara berbeda oleh kedua media. Detik.com memaknai tagar dalam framing positif (sebagai wujud ekspresi politik simbolik publik yang tidak puas terhadap kebijakan pemerintahan); bahkan memberi dukungan politis pada kelompok oposisi. Sementara Kompas.com memaknai tagar dalam arti negatif (lemahnya klaim moral, adanya unsur pelanggaran hukum, dan mecurigai kelompok oposisi berada dibalik gerakan 'ganti presiden').

Relevansi keempat terlihat dari sisi 'realitas subjektif' (subjective reality)—yakni konstruksi makna realitas yang dihayati individu yang dikonstruksi melalui proses internalisasi-sebagai basis untuk melibatkan diri dalam proses interaksi sosial dengan individu atau kelompok dalam sebuah struktur sosial. Konteks ini tercermin dari (\#)2019GantiPresiden sebagai fenomena yang telah ter'objektivikasi' menjadi fakta sosial karena tagar (\#)2019GantiPresiden sebagai realitas sosial subjektif telah terkonstruksi sebagai hasil dari proses pemaknaan intrasubjektif (kesadaran publik yang lahir dari hasil interaksi, negosiasi, dan konsensus) yang sudah terpola dan terlembaga sebagai perilaku kolektif (proses eksternalisasi) dalam konteks pertarungan wacana politik pilpres 2019.

\section{PENUTUP}

Dari pembahasan dan analisis terkait aspek subjektivitas kekuasaan dalam pemberitaan Detik.com dan Kompas.com ditinjau dari keempat struktur analisis Pan-Kosicki dapat disimpulkan:

Pada judul berita 1, pemberitaan Detik.com cenderung menonjolkan penyusunan fakta berita pada kelompok pro tagar (\#)2019GantiPresiden. Strategi framing dapat dilihat dari: (a) penempatan tanda tanya [?] pada judul berita (makna 'kontroversi' berita); (b) apresiasi pada gerakan yang diinisiasi oleh kelompok pro tagar (\#)2019GantiPresiden; (c) Presiden Jokowi diposisikan sebagai narasumber tunggal (aktor dominan); (d) konstruksi presiden sebagai sosok yang reaktif, arogan, dan subjektif; (e) tidak ada aspek koherensi dalam penyusunan fakta berita; (f) tidak menjawab aspek why dan how yang melatari penulisan fakta berita; (g) penggunaan leksikon yang bermakna ganda; (h) kalimat penutup bermotif 'menyindir'; (i) penempatan foto presiden untuk memperjelas fakta berita; dan (j) framing negatif terkait kritik presiden pada tagar (\#)2019GantiPresiden).

Pada judul berita 2, strategi framing yang dilakukan Detik.com dapat dilihat dari: (a) pemberian atribusi positif para relawan pro tagar (\#)2019GantiPresiden; (b) mencurigai netralitas pemerintah pada pemilu 2019; (c) pemberian makna positif pada sosok Ali Sera (positioning Ali Sera sebagai aktor tunggal deklarator dalam penulisan fakta berita); (d) narasi berita bersifat monologis; (e) pemberian legitimasi pada kelompok pro tagar (\#)2019GantiPresiden; (f) ada aspek kohesi dan koherensi dalam fakta berita; (g) menjawab aspek why dan how dalam penyusunan fakta 
berita; (h) leksikon bersifat kritik; (i) metafor bernuansa idealis-patriotis; (j) penempatan foto relawan \#2019GantiPresiden untuk memperjelas fakta berita; (k) kalimat penutup yang bermakna permisif; dan (1) framing berita terkait pilpres 2019 bersifat negatif (bermakna konotatif).

Pada judul berita 3, strategi framing yang dilakukan Kompas.com dapat dilihat dari: (a) ada penonjolan berita pada kelompok kontra tagar (\#)2019GantiPresiden; (b) kalimat pada judul berita yang bersifat 'kontradiktif'; (c) memberi atribusi 'antagonis' pada sumber berita; (d) ada ruang diskusi dan edukasi publik terkait isu tagar; (e) ada apresiasi pada kelompok pendukung tagar; (f) narasumber diposisikan secara seimbang; (g) narasi berita bersifat dialogis; (h) konstruksi positif pada Ali Sera dan negatif pada Romi; (i) ada aspek koherensi dan kohesi dalam penulisan fakta berita; (j) menjawab aspek why dan how yang melatari fakta berita; (k) menggunakan leksikon yang bermakna normatif; (i) kalimat penutup yang bernuansa 'konfliktual'; (l) penempatan foto Romi untuk memperjelas fakta berita; dan (m) framing positif perang tagar sebagai isu strategis.

Pada judul berita 4, strategi framing yang dilakukan Kompas.com dapat dilihat dari: (a) atribusi yang cenderung 'negatif' (sikap curiga) pada kelompok pro tagar (\#)2019GantiPresiden (oposisi); (b) penonjolan aspek 'pelanggaran hukum'; (c) penggunaan kalimat konjungtif; (d) tidak ada aspek kohesi (keterpaduan bentuk kalimat) dan koherensi (keterpaduan makna kalimat) dalam penyusunan fakta berita; (e) narasi berita bersifat subjektif dan didominasi pemaknaan tunggal wartawan Kompas.com; (f) pemberitaan legitimasi pada kelompok pro tagar (\#)Lanjutkan212 (pro Jokowi); (g) tidak menjawab aspek why dan how; (h) menggunakan metafor bermakna negatif (kalimat tanya?); (i) penggunaan leksikon bermakna subjektif; (j) penempatan foto peserta CFD (pengguna kaus bertagar (\#)2019GantiPresiden) untuk mempertegas penyusunan fakta berita; dan (k) framing negatif pada peserta CFD pengguna kaus/atribut berlogo tagar (\#)2019GantiPresiden.

Jika kita tinjau dari elemen sintaksis, skrip, tematik, dan retoris terlihat adanya penyelipan aspek subjektivitas kekuasaan dalam pemberitaan Detik.com dan Kompas.com. Melalui perangkat analisis bahasa pada keempat elemen analisis ditemukan kecenderungan framing positif pada teks berita (\#)2019GantiPresiden di Detik.com. Sebaliknya, Kompas.com memberi framing negatif pada tagar (\#)2019GantiPresiden yang digunakan sebagai simbol perlawanan kelompok anti Jokowi.

Kajian ini menyimpulkan terdapat motif subjektivitas kekuasaan pada framing berita di kedua portal berita dengan variasi, aksentuasi, dan derajat yang berbeda. Kajian ini merekomendasikan pada khalayak pembaca agar bersikap lebih kritis dan selektif dalam membaca berita media. Peneliti juga menyarankan agar praktisi media 'menyampaikan peristiwa apa adanya' (objektif) bukan 'menciptakan/merekayasa peristiwa' (subjektif). Di level pemilik media, kedua portal berita diharapkan dapat memberi pencerdasan pada publik serta dapat menerapkan prinsip pemberitaan yang lebih objektif, profesional, proporsional, dan seimbang (cover both sides).

\section{Ucapan Terima Kasih}

Penulis menyampaikan terimakasih kepada rekan-rekan dosen di FISIP USNI, FISIP UBK, dan STIKOM Muhammadiyah Jayapura; khususnya kepada Kepala BPSDMP Kominfo Jakarta, Pimpinan Redaksi Jurnal Studi Komunikasi \& Media serta para editor dan Mitra Bestari yang telah memberi kesempatan kepada penulis untuk menerbitkan naskah artikel ini.

\section{DAFTAR PUSTAKA}

Adian, Doni Gahral (2002). Menyoal Objektifitas Ilmu Pengetahuan. Jakarta: Traju.

Althusser, Louis (2015). Ideologi dan Aparatus Ideologi Negara (Catatan-catatan Investigasi). Jakarta: IndoPROGRESS.

Ayuningtyas, Paramita (2009). Identitas Diri yang Dinamis: Analisis Identitas Gender dalam Novel Breakfast on Pluto Karya Patrick Mc.Cabe (Thesis). Retrieved from http://lib.ui.ac.id/file?file=digital/20251276RB00P38i-Identitas diri.pdf.

Badsey, S. (1994). Philip M. Taylor, War and the Media: Propaganda and Persuasion in the Gulf War (Book Reviews). Journal of Conflict Studies, 14(3), 68-69. Retrieved from https://journals.lib.unb.ca/index. php/JCS/article/view/15197. 
Berger, Peter L. and Thomas Luckmann (1966). The Social Construction of Reality: A Treatise in the Sociology of Knowledge. Retrivied from http://perflensburg.se/Berger\%20social-construction-ofreality.pdf.

Berger, Peter L. dan Thomas Luckmann (1990). Tafsir Sosial Atas Kenyataan: Risalah Sosiologi Pengetahuan. Cetakan Kesepuluh. Jakarta: LP3ES.

Boothman, Derek (2008). The Sources for Gramsci's Concept of Hegemony. Rethinking Marxism, 20(2) 201-215. DOI: 10.1080/0893569080191694. Retrivied from https://people.duke.edu/ dainotto/Texts/ boothman.pdf

Bungin, Burhan (2006). Analisis Data Penelitian Kualitatif. Jakarta: RajaGrafindo.

Bungin, Burhan (2015). Konstruksi Sosial Media Massa: Kekuatan Pengaruh Iklan Media Massa, Televisi, dan Keputusan Konsumen Serta Kritik Terhadap Peter L. Berger dan Thomas Luckmann. Cetakan ke3. Jakarta: Prenadamedia Group.

Croteau, David and William Hoynes (2000). The Business of Media: Corporate Media and The Public Interest (First Edition). Thousand Oaks, California, London, New Delhi: Pine Forge Press.

Edelstein, Alex S. (1997). Total Propaganda: From Mass Culture To Popular Culture. New Jersey: Lawrence Elbraum Associates.

Eriyanto (2002). Analisis Framing: Konstruksi, Ideologi, dan Politik Media. Yogyakarta: LKiS.

Fairclough, Norman (1995). Media Discourse. London: Edward Arnold.

Fillingham, Lydia Alix (2001). Foucault Untuk Pemula. Jakarta: Kanisius.

Fowler, Roger (1991). Language in the News: Discourse and Ideology in the Press. London: Routledge.

Giddens, Anthony (2010). Teori Strukturasi: Dasar-dasar Pembentukan Struktur Sosial Masyarakat. Yogyakarta: Pustaka Pelajar.

Habermas, Jurgen (2007). Ruang Publik: Sebuah Kajian Tentang Kategori Masyarakat Borjuis. Bantul: Kreasi Wacana.

Hamad, Ibnu (2004). Konstruksi Realitas Politik dalam Media Massa: Sebuah Studi Critical Discourse Analysis Terhadap Berita-berita Politik. Jakarta: Granit.

Hamad, Ibnu (2007). Lebih Dekat dengan Analisis Wacana. Mediator, 2(8), 325-344. https://doi.org/10. 29313/mediator.v8i2.1252.

Hakim, Rakhmat Nur (2018). Muncul Tagar \#2019GantiPresiden, PPP Usul Tagar \#Lanjutkan212. Retrieved March 20, 2019, from https://nasional.Kompas.com/read/2018/04/04/18183831/muncul-tagar-2019 gantipresiden-ppp-usul-tagar-lanjutkan212.

Hayakawa, Samuel Ichiye (1946). Language in Thought and Action. New York: Harcourt Brace Jovanovich. Jackal, Robert (1995). Propaganda. New York University Press, Eiseman.

Jordan, Ray (2018). Jokowi Sindir \#2019GantiPresiden: Masak Kaus Bisa Ganti Presiden? Retrieved March 20, 2019, from https://news.Detik.com/berita/3958859/jokowi-sindir-2019gantipresiden-masak-kausbisa-ganti-presiden.

Jowett, Garth S. and Victoria O’Donnell (2012). Propaganda and Persuasion (Fifth Edition). California: SAGE Publications, Inc, Thousand Oaks. Retrieved from https://hiddenhistorycenter.org/wp-content/ uploads/2016/10/PropagandaPersuasion2012.pdf.

Kamahi, Umar (2017). Teori Kekuasaan Michel Foucault: Tantangan Bagi Sosiologi Politik. Jurnal AlKhitabah, 1(3), 117-132. http://journal.uin-alauddin.ac.id/index.php/Al-Khitabah/article/view/2926.

Kompas.com: Jernih Melihat Dunia. Retrieved March 20, 2019, from https://inside.Kompas.com/about-us.

Kotler, Philip and Waldemar Pfoertsch (2006). B2B Brand Management. Berlin: Springer. Palgrave.

Lefebvre, Henri (2000). The Production of Space. New York: Georgetown University Press.

Maharani, Tsarina (2018). Relawan \#2019GantiPresiden Bacakan Aspirasi Nasional, Ini Isinya. Retrieved March 21, 2019, from https://news.Detik.com/berita/d-4007122/relawan-2019gantipresiden-bacakanaspirasi-nasional-ini-isinya.

McQuail, Denis (1991). Teori Komunikasi Massa: Suatu Pengantar (Edisi Kedua). Jakarta: Penerbit Erlangga.

Meyers, Herbert M. and Richard Gerstman (ed.) (2001). Branding @ the Digital Age. New York: Palgrave.

Merrill, John C. (1965). How Time Stereotyped Three U.S. Presidents. Journalism \& Mass Communication Quarterly. 4(42), 563-570. https://doi.org/10.1177/107769906504200406.

Moss, Peter D. (1999). "Conflict and Containment in Television News: A Case Study," in Mary S. Mander (ed.). Framing Friction: Media and Social Conflict. Urbana: University of Illinois Press.

Mujianto (2011). Pertarungan Kekuasaan dalam Teks Media, Studi Analisis Wacana Kritis: Kasus Mesuji dalam Koran Jawa Pos. Jurnal Linguistik Terapan, 2(1), 1-14. Retrieved from http://jlt-polinema.org/? $\mathrm{p}=132$.

Muslich, Masnur (2008). Kekuasaan Media Massa Mengonstruksi Realitas. Jurnal Bahasa dan Seni, 2(36), 150-159. Retrieved from http://sastra.um.ac.id/wp-content/uploads/2009/10/Kekuasaan-Media-Massa- 
Mengontruksi-Realitas-Masnur-Muslich.pdf.

Nazaruddin, Kahfie (2015). Pengantar Semiotika. Yogyakarta: Graha Ilmu.

Piliang, Yasraf Amir (2004). Postrealitas: Realitas Kebudayaan dalam Era Post Metafisika. Jakarta: Jalasutra.

Poloma, Margaret M. (2010). Sosiologi Kontemporer. Jakarta: Rajawali Press.

"Propaganda," in Merriam Webster (2006). Retrieved April 11, 2020, from https://www.merriam-webster. com/dictionary/propaganda.

Rahardjo, Mudjia (2018). Paradigma Interpretif, 1-5 (March 19, 2019). Retrieved from http://repository.uinmalang.ac.id/2437/1/2437.pdf.

Ramos Jr., Valeriano (1982). The Concepts of Ideology, Hegemony, and Organic Intellectuals in Gramsci's Marxism. Theoretical Review No. 27, March-April. Retrieved from https://www.marxists.org/history/ $\mathrm{erol} / \mathrm{ncm}-7 /$ tr-gramsci.htm.

Saverin, Warner J. dan James W. Tankard Jr. (2011). Teori Komunikasi: Sejarah, Metode, dan Terapan di dalam Media Massa. Cetakan ke-5. Jakarta: Kencana.

Schroeder, Jonathan E. (2002). Visual Consumption. London: Routledge.

Scriver, Stacey (2015). War Propaganda. International Encyclopedia of the Social \& Behavioral Sciences. 25(2), 395-400. DOI: 10.1016/B978-0-08-097086-8.96046-X. Retrieved from https://www.research gate.net/publication/304184774_War_Propaganda.

Sejarah Berdirinya Detik.com (2012). Retrieved March 17, 2019, from https://greenp4r4hyangan. wordpress.com/2012/04/07/sejarah-berdirinya-detik-com/

Sobur, Alex (2012). Analisis Teks Media: Suatu Pengantar Analisis Wacana, Analisis Semiotik, dan Analisis Framing. Bandung: Remaja Rosdakarya. 